\title{
Hydrochemical characterization of groundwater in wadi Sayyah, Western Saudi Arabia
}

\author{
Masoud Eid Al-Ahmadi
}

Received: 13 February 2013/Accepted: 17 June 2013/Published online: 9 July 2013

(c) The Author(s) 2013. This article is published with open access at Springerlink.com

\begin{abstract}
Groundwater is an essential and vital component of our life support system where it is used for drinking, irrigation, and industrial purposes. Wadi Sayyah is one of the most important wadis in the western part of Saudi Arabia to the northeast of Jeddah city. A total of 42 groundwater samples are collected from hand dug wells in this area and they are analyzed for various physical and chemical parameters. The sequence of the abundance of the major ion is in the following order: $\mathrm{Ca}^{2+}>\mathrm{Na}^{+}>\mathrm{Mg}^{2+}>\mathrm{K}^{+}$and $\mathrm{Cl}^{-}>\mathrm{SO}_{4}{ }^{2-}>\mathrm{HCO}_{3}{ }^{-}>\mathrm{NO}_{3}{ }^{-}$. The dominated hydrochemical facieses of groundwater are: $\mathrm{CaCl}$, and mixed $\mathrm{CaMgCl}$, and the alkaline earths $\left(\mathrm{Ca}^{2+}, \mathrm{Mg}^{2+}\right)$ and strong acids $\left(\mathrm{SO}_{4}{ }^{2-}, \mathrm{Cl}^{-}\right)$are dominating over alkalis $\left(\mathrm{Na}^{+}, \mathrm{K}^{+}\right)$ and weak acids $\left(\mathrm{HCO}_{3}^{-}, \mathrm{CO}_{3}^{-}\right)$. Statistical analysis indicates positive correlation among most of the chemical parameters. Based on the analytical results, groundwater in the study area is generally hard to very hard, fresh to brackish and alkaline in nature. The rock weathering and evaporation are among the most dominant processes in controlling water quality. The chloro-alkali indices illustrate that $80 \%$ of the water samples have positive indicating exchange of $\mathrm{Na}^{+}$and $\mathrm{K}^{+}$from water with $\mathrm{Mg}^{2+}$ and $\mathrm{Ca}^{2+}$ from the rock. The suitability of water for drinking and irrigation is determined using WHO standards for drinking; some indices for irrigation purposes and it indicate that the groundwater in the study area can be used for drinking purposes in most of the locations (31 wells), while it is suitable for irrigation uses.
\end{abstract}

M. E. Al-Ahmadi ( $\square)$

Hydrogeology Department, Faculty of Earth Sciences,

King Abdulaziz University, P.O. Box 80206,

Jeddah 21589, Saudi Arabia

e-mail: m_al_ahmadi@yahoo.com
Keywords Groundwater - Chemical classification . Hydrochemical analysis - Wadi Sayyah - Saudi Arabia

\section{Introduction}

Groundwater is an essential and vital resource world wide. It was estimated that approximately one-third of the world's population uses groundwater for drinking (UNEP 1999). Saudi Arabia (SA) is located in the arid zone of south west Asia, where there is no perennial river or surface water. Groundwater is the primary source of the water for human consumption, as well as for agricultural and industrial uses, which make it an important resource in SA. So, growing population, agricultural expansion and urbanization has placed a heavy demand on water resources, which are among the challenging issues especially in arid and semi-arid regions, where the water resources are limited. The fresh water resources are limited to the groundwater system, where the groundwater in alluvial aquifer, which is dependent on direct recharge of rainfall. Wadi Sayyah is one of the important wadis for Al Kamel and surround villages in the western part of SA. Groundwater in the study area has special significance, where it is the only source for freshwater, which is used for domestic and agricultural needs in ascending order.

Water quality is important as for its quantity and quality as it moves through the soils and sediments, and hence, its composition is then changed by chemical reactions such as weathering, dissolution, leaching, precipitation, ion exchange, impact of agriculture and urbanization. The quality of groundwater has been studied in several basin by many researchers (Ramesh and Bhuvana 2012; Magnus et al. 2011; Cobbina et al. 2012; Emmannoel et al. 2009). 
The important of the groundwater in this area has been underestimated. This is due to the fact that it is the only water resource for drinking and agricultural purposes for people and for other living beings in the surrounding area.

Shallow groundwater resources provide important fresh water in many parts of the SA, where surface water supplies are absent except during the floods after intensive rainfall occurrences. Extensive agricultural activities and high growth of rural and metropolitan activities result in increased demand for development of groundwater resources.

However, no studies have been carried out in this area for groundwater resources; so, this study is the first one in this region. This work aims to hydro-geochemical investigation, which is carried out to identify groundwater geochemistry and its suitability for drinking and irrigation purposes.

\section{Study area}

The study is done in wadi Sayyah, which lies in the Rabigh region which is one of the major tributary of wadi Khulais in the central western SA. It is located in the northeastern Jeddah city at a distance of $160 \mathrm{~km}$ between latitudes $22^{\circ} 15^{\prime}$ and $22^{\circ} 30^{\prime} \mathrm{E}$ and longitudes $39^{\circ} 45^{\prime}$ and $40^{\circ} 00^{\prime} \mathrm{N}$ (see Fig. 1). Rainfall in the western SA can be described as scare and unpredictable, but very extensive during local storms. The rate of evaporation is very high on the average of $400 \mathrm{~mm} /$ year (Şen 1983).

This wadi is considered as important to agricultural areas in the Red Sea coastal region, where it supplies water to near cities and villages as for their vegetable, fruit, and dates requirements. This wadi is located at an elevation of about 381-723 m above mean sea level. Wadi Sayyah flows through stream of an irregular shape and direction, which is generally from east to west. The climate of the area is of arid type with the average daily maximum temperature at $35{ }^{\circ} \mathrm{C}$ in the summer and the minimum $16{ }^{\circ} \mathrm{C}$ in the winter. The annual rainfall is greater than $140 \mathrm{~mm}$. Runoff occurs most of the year especially after rainfall as flash floods associated with heavy short-duration storms in the winter and spring (Şen 1983).

Geologically, the study area is a part of the Arabian Shield that extends from the north to the south parallel to the Red Sea. This Shield is made up of Precambrian crystalline, metamorphic and meta-volcanic sedimentary rocks (Moore and Al-Rehalie 1989). The geology can be categorised into four units as follows:

1. Precambrian layered rocks, that consist of (a) Samaran group which is represented by Amudan formation ( $\mathrm{Sa}$ ). This crops out in a northeast trend of the quadrangle and it consists mainly of lava, pyroclastic rocks with
Fig. 1 Location map of the study area

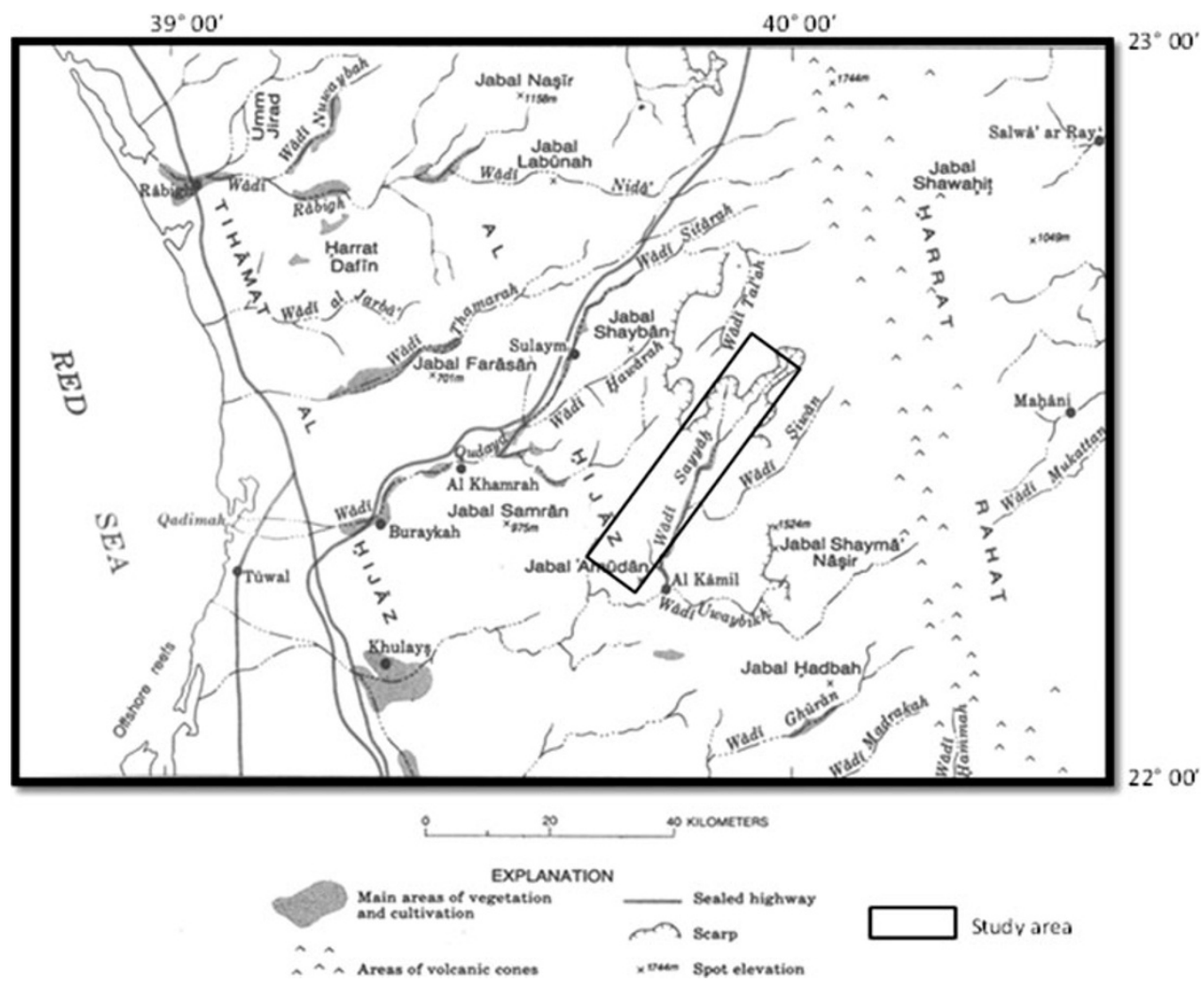


some ignimbrite and epiclastic rock which is the main exposure in this wadi and AlKamil (Ramsay 1986). (b) Shayma Nasir group which is represented by Uaibikh formation (nu) located east of Al Kamil which consists of Andesitic, dacitic lava, volcaniclastics minor basalt, rhyolite, conglomerate, and sandstone.

2. Tertiary rocks These units are represented by Hammah formation (trnb) which consists of AlKali olivine basalt, subordinate alkalic intermediate lava, minor pyroclastic, and some feldspathoidal lava.

3. Precambrian intrusive rocks These intrusive rocks are represent by Shiwan complex which occupy many places throughout the study area, they consist of Diorite to Quartz Diorite (Kwdi), Hornblende Tonalite (Kwtn), Hornblende-Biotite Tonalite (Kwtt),
Granodiorite to Quartz Monzonite (Kwtg) and Honrnblend-biotit Monzogranite (Kwgm).

4. Quaternary deposits The floor of Wadi Sayyah is filled with quaternary alluvial deposits which are the weathering products of the host rock units in the area. This alluvial is mainly composed of medium to coarse grained gravel along the wadi channels and fine sands in the flat area.

The predominant structural feature is in the form of normal faults that strike roughly north-northwestward along the margin of the Red Sea (see Fig. 2).

The groundwater of the area occurs under unconfined conditions. Rainfall infiltration and seepage of water from irrigation water are responsible for groundwater fluctuation. More than 60 wells exist within the main course of
Fig. 2 Geologic map of Rabigh area (Ramsay 1986)

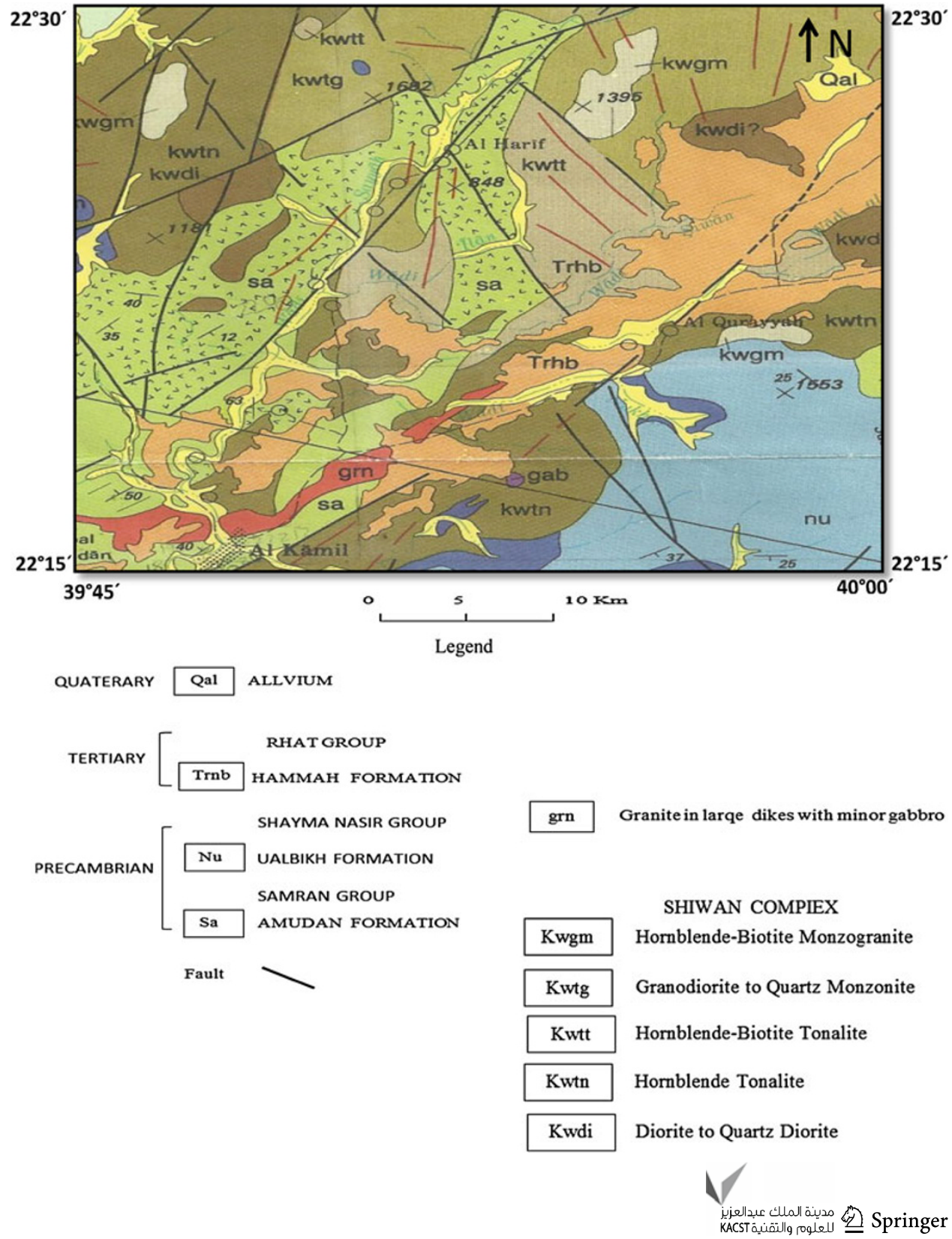


Wadi Sayyah. These wells are shallow and partially penetrating. This is due to the fact that the farmers stop further deepening the well when they reached to considerable depth of water column. On the average, the depth of wells in this area reaches to $27.7 \mathrm{~m}$. These are large diameter dug wells, where the diameter varied from 1.5 to $8 \mathrm{~m}$. Generally, the groundwater depth in wadi Sayyah area varies in the range of 7.3-24.45 m. Some of the area is covered by agricultural land. Groundwater is drawn from an unconfined alluvial, fractured-type aquifer. Fruits and date is the dominating cropping system in the region under surface irrigation (flooding and basin).

\section{Methodology}

A total of 42 wells served in June 2011 (Fig. 3), which corresponded to dry season. Groundwater level depths are measured. Each well is purged before the ground water samples are collected. The electrical conductivity (EC), and $\mathrm{pH}$ values are measured in the field, because these parameters are likely to change during transport. These variables are measured using a portable field kit. At the time of sampling, the bottles are thoroughly rinsed 2-3 times using the same groundwater. The samples are analyzed for major cations $\left(\mathrm{Na}^{+}, \mathrm{K}^{+}, \mathrm{Ca}^{2+}\right.$, and $\left.\mathrm{Mg}^{2+}\right)$; and anions $\left(\mathrm{Cl}^{-}, \mathrm{SO}_{4}{ }^{2-}, \mathrm{HCO}_{3}{ }^{-}\right)$and minor ions such as fluoride $\left(\mathrm{F}^{-}\right)$, nitrate $\left(\mathrm{NO}_{3}{ }^{-}\right)$, and phosphate $\left(\mathrm{PO}_{4}{ }^{3-}\right)$. The chemical analysis is carried out in the laboratory of the Faculty of Earth Sciences Jeddah as per the procedure given in the American Pubic Heath Association (APHA 2005). Calcium $\left(\mathrm{Ca}^{2+}\right)$ and magnesium $\left(\mathrm{Mg}^{2+}\right)$ are determined titrimetrically using standard EDTA. Chloride $\left(\mathrm{Cl}^{-}\right)$ is determined by standard $\mathrm{AgNO}_{3}$ titration. Bicarbonate $\left(\mathrm{HCO}_{3}{ }^{-}\right)$are determined by titration with $\mathrm{HCl}$. Sodium $\left(\mathrm{Na}^{+}\right)$and potassium $\left(\mathrm{K}^{+}\right)$are measured by flame photometry. Sulfate $\left(\mathrm{SO}_{4}{ }^{2-}\right)$ and nitrate $\left(\mathrm{NO}_{3}{ }^{-}\right)$, and fluoride $\left(\mathrm{F}^{-}\right)$, are determined colorimetrically using spectrophotometer technique.

The analytical precision of the ions measurement is determined by calculating the absolute error in ionic balance, which is found in all samples within a standard limit of $+5 \%$ (Domenico and Schwartz 1998).

\section{Results and discussion}

\section{Groundwater chemistry}

The statistical parameters of the chemical composition of the groundwater such as minimum, maximum, mean, and standard deviation are presented in Table 1 . The $\mathrm{pH}$ value in most of the water samples range 6.5-7.7 with mean value of 7.14. Only few samples have values less than 7 . All other samples have values more than 7 , which indicate alkaline nature of the samples. The values of $\mathrm{pH}$ are found to be in the permissible range of 7-8.5 according to WHO standards. The values of EC range from 704 to $4,848 \mu \mathrm{S} / \mathrm{cm}$ with mean of $2,098.38 \mu \mathrm{S} / \mathrm{cm}$. The large variations in EC are attributed mainly to geochemical
Fig. 3 Location of Groundwater samples in the study are

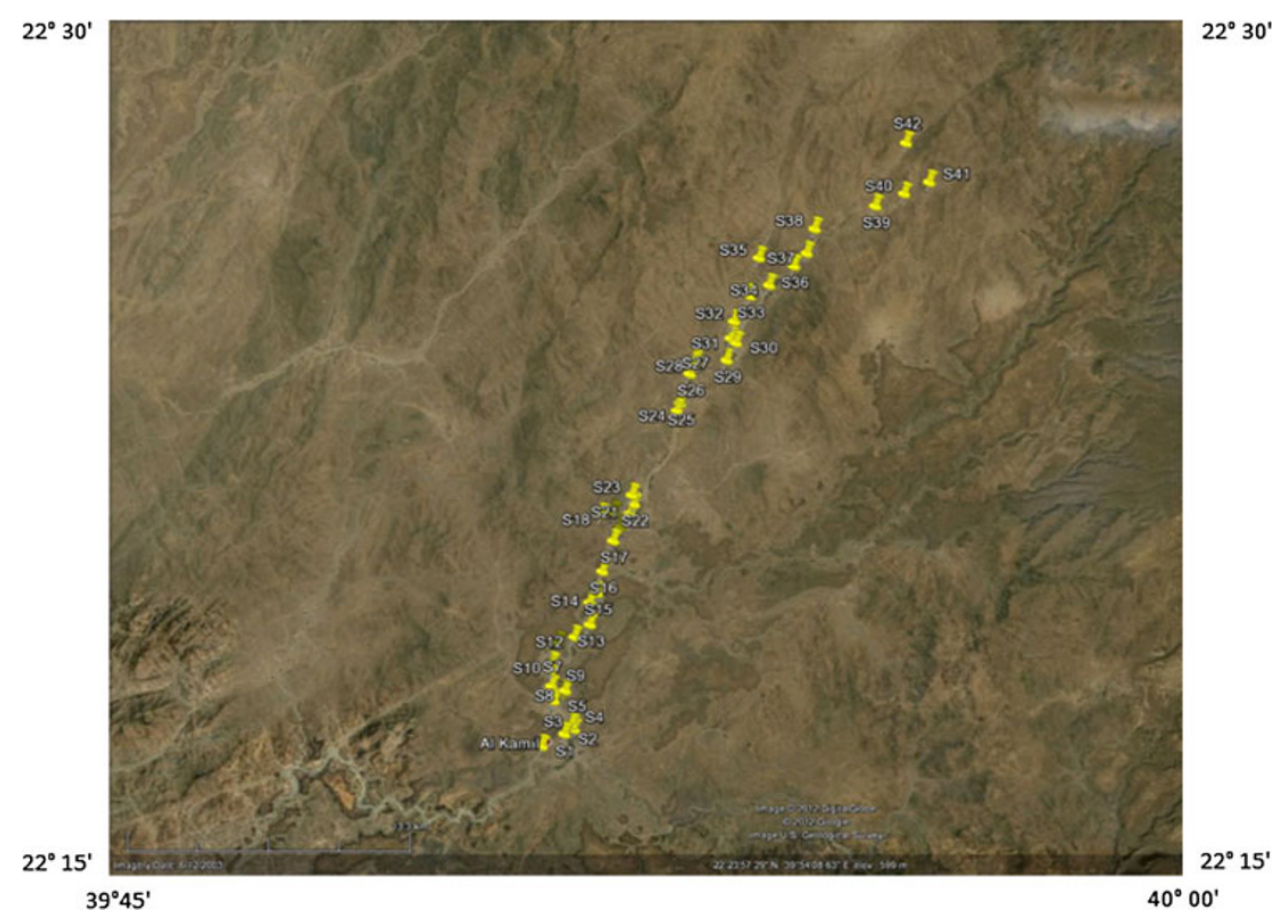


Table 1 Summary statistics of the hydrochemical variables for the data in the study area

\begin{tabular}{|c|c|c|c|c|c|}
\hline Parameters & Units & Minimum & Maximum & Mean & SD \\
\hline $\mathrm{pH}$ & - & 6.5 & 7.7 & 7.14 & 0.28 \\
\hline $\mathrm{EC}$ & $\mu \mathrm{S} / \mathrm{cm}$ & 704 & 4,848 & $2,098.38$ & $1,556.95$ \\
\hline TDS & $\mathrm{mg} / \mathrm{l}$ & 468 & 2,688 & $1,355.36$ & 969.16 \\
\hline $\mathrm{Ca}$ & $\mathrm{mg} / \mathrm{l}$ & 70.70 & $1,076.40$ & 231.09 & 198.71 \\
\hline $\mathrm{Mg}$ & $\mathrm{mg} / \mathrm{l}$ & 13.80 & 272.40 & 54.65 & 53.76 \\
\hline $\mathrm{Na}$ & $\mathrm{mg} / \mathrm{l}$ & 34.30 & 931.80 & 156.30 & 149.55 \\
\hline K & $\mathrm{mg} / \mathrm{l}$ & 1.30 & 15.40 & 6.24 & 2.22 \\
\hline $\mathrm{Cl}$ & $\mathrm{mg} / \mathrm{l}$ & 102.70 & $2,850.10$ & 438.62 & 485.93 \\
\hline $\mathrm{HCO}_{3}$ & $\mathrm{mg} / \mathrm{l}$ & 122.70 & 294.50 & 188.75 & 46.01 \\
\hline $\mathrm{SO}_{4}$ & $\mathrm{mg} / \mathrm{l}$ & 118.40 & $1,755.20$ & 355.84 & 301.28 \\
\hline $\mathrm{NO}_{3}$ & $\mathrm{mg} / \mathrm{l}$ & 11.70 & 450.20 & 56.97 & 69.04 \\
\hline $\mathrm{F}$ & $\mathrm{mg} / \mathrm{l}$ & 0.35 & 1.50 & 0.73 & 0.33 \\
\hline $\mathrm{PO}_{4}$ & $\mathrm{mg} / \mathrm{l}$ & 0.05 & 0.79 & 0.18 & 0.16 \\
\hline SAR & - & 3.45 & 0.31 & 1.74 & 0.55 \\
\hline RSC & meq/1 & -72.80 & -2.78 & -12.94 & 13.99 \\
\hline T H & $\mathrm{mg} / \mathrm{l}$ & 248.56 & $3,808.70$ & 801.93 & 709.28 \\
\hline CAI 1 & $\mathrm{meq} / \mathrm{l}$ & -0.02 & 0.89 & 0.35 & 0.22 \\
\hline CAI 2 & meq/l & -0.13 & 0.95 & 0.40 & 0.30 \\
\hline
\end{tabular}

$p H$ hydrogen ion concentration, $S A R$ sodium absorption ratio, $R S C$ residual sodium carbonate, $E C$ electrical conductivity, $T D S$ total dissolved solids, $T H$ total hardness, CAI 1, 2 Chloro-alkaline index

processes prevailing in this region. A high percentage of the TDS is contributed by $\mathrm{Ca}^{2+}, \mathrm{Mg}^{2+} \mathrm{Na}^{+}, \mathrm{Cl}^{-}$, and $\mathrm{SO}_{4}{ }^{2-}$. Also the $\mathrm{EC}$ values are influenced by $\mathrm{Ca}^{2+}, \mathrm{Mg}^{2+}$ $\mathrm{Na}^{+}, \mathrm{Cl}^{-}$, and $\mathrm{SO}_{4}{ }^{2-}$ as it is clear from Table 2 according to Pearson correlation between the major ions. The total dissolved solids (TDS) in the study area varied from 468 to
$2,688 \mathrm{mg} / \mathrm{l}$ with a mean value $1,355.36 \mathrm{mg} / \mathrm{l}$. The large variation in TDS is mainly attributed to anthropogenic activities and to geochemical processes prevailing in the area (Choi et al. 2005). Based on TDS classifications (Freeze and Cherry 1979; Hem 1989), $62 \%$ of the groundwater in the study area belongs to brackish type (TDS $>1,000 \mathrm{mg} / \mathrm{l}$ ) and the remaining was fresh water (TDS $<1,000 \mathrm{mg} / \mathrm{l}$

The abundance of the major ions is as follows: $\mathrm{Ca}^{2+}>\mathrm{Na}^{+}>\mathrm{Mg}^{2+}>\mathrm{K}^{+}$and $\mathrm{Cl}^{-}>\mathrm{SO}_{4}{ }^{2-}>\mathrm{HCO}_{3}{ }^{-}$ $>\mathrm{NO}_{3}{ }^{-}$.

In the study area, the calcium $\left(\mathrm{Ca}^{2+}\right)$, which is very common in the groundwater is a variable in most of the rocks with its concentration variation between 70.7 and $1,076.4 \mathrm{mg} / \mathrm{l}$ with mean of $231.09 \mathrm{mg} / 1$. Magnesium $\left(\mathrm{Mg}^{2+}\right)$ normally occurs in lesser concentration than other cations. This is due to the fact that dissolution of magnesiumrich minerals is slow processor, the concentration of $\mathrm{Mg}^{2+}$ in the groundwater in the study area is found to vary between 13.80 and $272.40 \mathrm{mg} / \mathrm{l}$ with a mean value of $54.65 \mathrm{mg} / \mathrm{l}$. Sodium $\left(\mathrm{Na}^{+}\right)$concentrations are found in groundwater in this study area and they range from 34.30 to $931.80 \mathrm{mg} / \mathrm{l}$ and the mean 156.mg/l. High concentrations of $\mathrm{Na}^{+}$in the groundwater are attributed to cation exchange among minerals. The concentration of potassium $\left(\mathrm{K}^{+}\right)$is measured and found to range from 1.30 to $15.40 \mathrm{mg} / \mathrm{l}$, while the mean is $6.24 \mathrm{mg} / \mathrm{l}$. Potassium ions present in the groundwater might have come from irrigation return flow.

The main source of bicarbonate $\left(\mathrm{HCO}_{3}{ }^{-}\right)$anion in the groundwater is from the dissolution of minerals such as calcite and dolomite, where its concentration ranges from 122.70 to $294.50 \mathrm{mg} / \mathrm{l}$ with mean value as $188.75 \mathrm{mg} / \mathrm{l}$.

Table 2 Correlation matrix for different water quality parameters in wadi Sayyah

\begin{tabular}{|c|c|c|c|c|c|c|c|c|c|c|c|c|c|c|c|c|}
\hline Parameter & $\mathrm{pH}$ & $\mathrm{EC}$ & TDS & $\mathrm{Ca}^{2+}$ & $\mathrm{Mg}^{2+}$ & $\mathrm{Na}^{+}$ & $\mathrm{K}^{+}$ & $\mathrm{HCO}_{3}{ }^{-}$ & $\mathrm{Cl}$ & $\mathrm{SO}_{4}^{2-}$ & $\mathrm{NO}_{3}^{-}$ & F & $\mathrm{PO}_{4}$ & $\mathrm{TH}$ & SAR & RSC \\
\hline $\mathrm{pH}$ & 1 & & & & & & & & & & & & & & & \\
\hline $\mathrm{EC}$ & 0.48 & 1 & & & & & & & & & & & & & & \\
\hline TDS & -0.48 & 0.98 & 1 & & & & & & & & & & & & & \\
\hline $\mathrm{Ca}^{2+}$ & -0.48 & 0.98 & 0.98 & 1 & & & & & & & & & & & & \\
\hline $\mathrm{Mg}^{2+}$ & -0.54 & 0.98 & 0.96 & 0.95 & 1 & & & & & & & & & & & \\
\hline $\mathrm{Na}^{+}$ & -0.47 & 0.89 & 0.91 & 0.89 & 0.85 & 1 & & & & & & & & & & \\
\hline $\mathrm{K}^{+}$ & -0.57 & -0.06 & -0.09 & -0.04 & 0.09 & 0.09 & 1 & & & & & & & & & \\
\hline $\mathrm{HCO}_{3}{ }^{-}$ & -0.78 & 0.30 & 0.32 & 0.28 & 0.71 & 0.23 & -0.08 & 1 & & & & & & & & \\
\hline $\mathrm{Cl}$ & -0.50 & 0.97 & 0.99 & 0.98 & 0.95 & 0.94 & -0.11 & 0.24 & 1 & & & & & & & \\
\hline $\mathrm{SO}_{4}{ }^{2-}$ & -0.50 & 0.94 & 0.95 & 0.96 & 0.90 & 0.94 & 0.05 & 0.28 & 0.95 & 1 & & & & & & \\
\hline $\mathrm{NO}_{3}^{-}$ & -0.55 & 0.79 & 0.71 & 0.75 & 0.81 & 0.51 & 0.10 & 0.11 & 0.67 & 0.64 & 1 & & & & & \\
\hline $\mathrm{F}$ & 0.03 & -0.13 & 0.13 & 0.15 & 0.03 & 0.28 & 0.07 & 0.20 & 0.14 & 0.23 & & 1 & & & & \\
\hline $\mathrm{PO}_{4}$ & 0.03 & -0.04 & -0.04 & 0.08 & -0.02 & -0.03 & 0.15 & -0.21 & -0.05 & -0.07 & 0.01 & -0.22 & 1 & & & \\
\hline $\mathrm{TH}$ & -0.51 & 0.99 & 0.99 & 0.99 & 0.97 & 0.89 & -0.05 & 0.28 & 0.98 & 0.95 & 0.78 & 0.11 & -0.06 & 1 & & \\
\hline SAR & 0.00 & -0.06 & -0.06 & -0.11 & -0.06 & 0.28 & -0.01 & -0.05 & -0.03 & -0.08 & -0.20 & 0.43 & 0.18 & -0.10 & 1 & \\
\hline RSC & 0.50 & -0.99 & -0.95 & -0.99 & -0.97 & -0.89 & -0.81 & -0.23 & -0.98 & -0.95 & -0.78 & -0.10 & 0.05 & -1.00 & 0.09 & 1 \\
\hline
\end{tabular}

The bold represents very high correlation between ions 


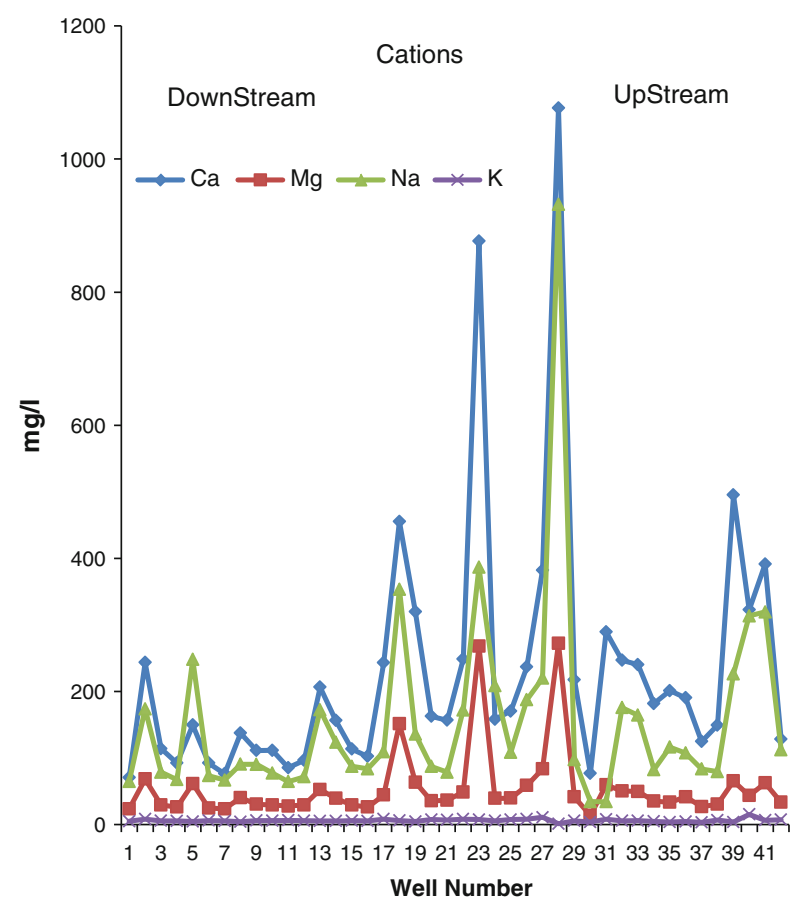

Fig. 4 change of cations and Anions concentration along the wadi

The high concentration of chloride $\left(\mathrm{Cl}^{-}\right)$in groundwater comes from weathering of minerals such as halite and other sources such as domestic effluents, fertilizer, septic tanks, and leachates from landfills (Loizidou and Kapetanios 1993). Chloride in the study area varies widely from 102.70 to $2,850.10 \mathrm{mg} / \mathrm{l}$ with a mean value of $438.62 \mathrm{mg} / \mathrm{l}$, where it increases from the recharge to discharge area.

Sulfate $\left(\mathrm{SO}_{4}{ }^{2-}\right)$ in the groundwater is derived principally from the evaporate minerals gypsum and the anhydrite. It could also come from oxidation of pyrite. Its concentration in this area varies from 118.40 to $1,755.20 \mathrm{mg} / \mathrm{l}$ with mean concentration $355.84 \mathrm{mg} / \mathrm{l}$ (see Table 1).

Nitrate $\left(\mathrm{NO}_{3}\right)$ sources in groundwater is due to decaying organic matter, sewage wastes, leakage of septic tanks, and fertilizers (Subrahmanyam and Yadaiah 2000), leaching of nitrate with the percolating water. Nitrate is found in high concentration in some of the wells throughout the study area. The $\mathrm{NO}_{3}{ }^{-}$concentration in the groundwater sample of this area show a large variation range from 11.70 to $450.20 \mathrm{mg} / \mathrm{l}$ with mean concentration of $56.97 \mathrm{mg} / \mathrm{l} .43 \%$ of the groundwater samples taken during this study show that nitrate concentration exceed the WHO limits $(50 \mathrm{mg} / \mathrm{l})$ in drinking water. The main source of nitrate contamination of groundwater in the study area may be from human and animals wasted and fertilizer.

Fluoride $(\mathrm{F})$ can be considered as one of the main trace element in groundwater where it is occur generally as natural constituent. The high concentration of fluoride is

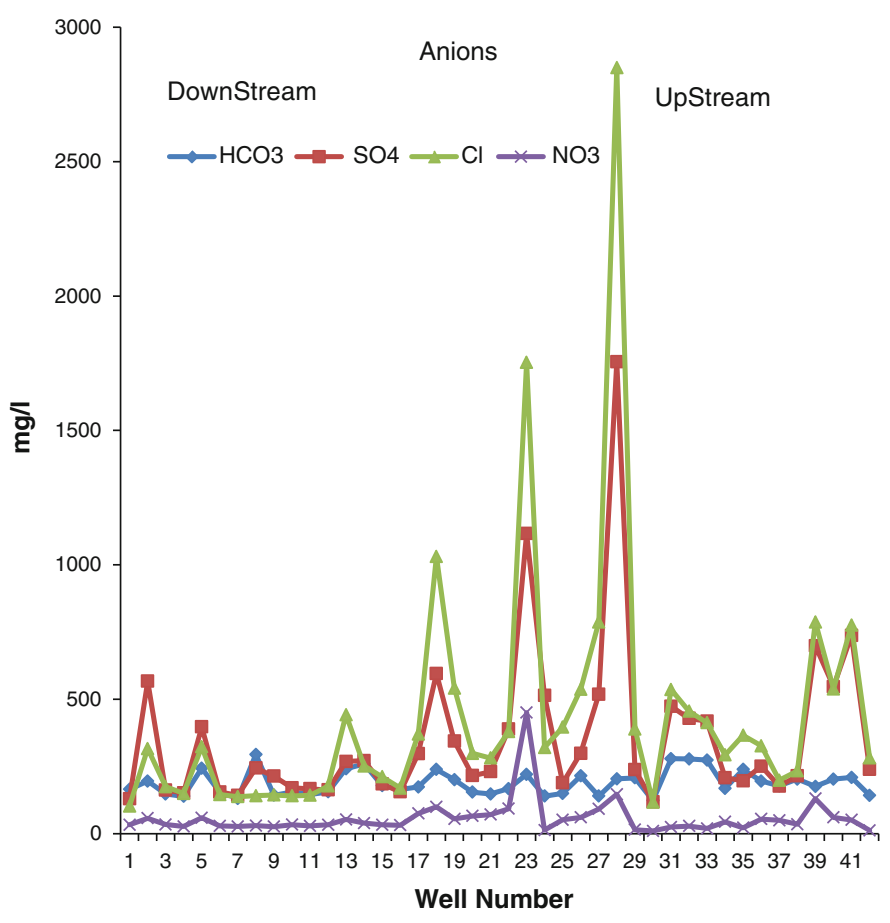

generally due to rocks containing fluoride minerals (Wenzel and Blum 1992; Bardsen et al. 1996). The concentration of fluoride in groundwater of the study area varies between 0.35 and $1.50 \mathrm{mg} / \mathrm{l}$ with a mean value of $0.73 \mathrm{mg} / \mathrm{l}$. Fluoride is considered as an essential element though health problems may arise from either deficiency or excess amount (Gopal and Gosh 1985).

The phosphate $\left(\mathrm{PO}_{4}\right)$ is usually found in groundwater only a minimal level. This is due to low solubility of native phosphate minerals and the ability to retain phosphate (Rajmohan and Elango 2005). The concentration of phosphate in groundwater in this area is observed from 0.05 to $0.79 \mathrm{mg} / \mathrm{l}$ with a mean value of $0.18 \mathrm{mg} / \mathrm{l}$.

The total hardness (TH) was found to be in the range of $248.56-3,808.75 \mathrm{mg} / \mathrm{l}$ with a mean value of $801.93 \mathrm{mg} / \mathrm{l}$.

The concentrations of cations and anions along wadi Sayyah is shown in Fig. 4 where it is seen that these concentrations fluctuate through this wadi. Also, it can be noted from this figure that the maximum values of these cations and anions were found in three wells $(18,23$ and 28). This may be due to the fact that wells drilled into rocks this is clears from the field study of these wells and as the recharge to these well is low, this is clear from the well No. 28 where it pumped only for half an hour then it is dried.

\section{Correlation matrix}

It is commonly used to examine the degree of correlation between the different chemical parameters, which affect 
the quality of groundwater. It is a simple measure to exhibit how well one variable predicts the other (Kurumbein and Graybill 1965). The Person's correlation matrices (Swan and Sandilands 1995) are used to find the relationships between two or more variables, where the correlation matrices between 14 chemical parameters were computed and presented in Table 2. Samples showing correlation coefficient $(r>0.7)$ are considered to be strongly correlated, where $(r)$ values between 0.5 and 0.7 show moderated correlation at a significance level $p=0.05$, while $r<0.3$ is weak. It is clear from Table 2 that there are high positive correlations between TDS and EC, which may be due to the fact that the conductivity increases as the concentration of all dissolved constituent increases. It also illustrate that $\mathrm{EC}$ and TDS show high positive correlation with $\mathrm{Ca}^{2+}, \mathrm{Mg}^{2+}, \mathrm{Na}^{+}, \mathrm{Cl}^{-}, \mathrm{SO}_{4}{ }^{2-}, \mathrm{NO}_{3}{ }^{-}$, and TH. The relationships clearly identify the main elements contributing to salinity of groundwater and their tendency to follow a similar trend. $\mathrm{Cl}^{-}$and $\mathrm{SO}_{4}{ }^{2-}$ are also significantly correlated with $\mathrm{Ca}^{2+}, \mathrm{Mg}^{2+}$, and $\mathrm{Na}^{+}$. A high relation between $\mathrm{TH}$ and $\mathrm{Ca}^{2+}, \mathrm{Mg}^{2+}$ and $\mathrm{Cl}^{-}$indicates that hardness in groundwater is mainly due to $\mathrm{CaCl}_{2}$ and $\mathrm{MgCl}_{2}$ (Udayalaxmi et al. 2010).

There is a very high positive correlation between $\mathrm{Cl}^{-}$ and $\mathrm{Na}^{+}(0.94)$ as well as between $\mathrm{Mg}^{2+}$ and $\mathrm{Cl}^{-}(0.95)$ due to the dissolution of evaporates. The high correlation matrix between $\mathrm{Ca}^{2+}$ and $\mathrm{NO}_{3}{ }^{-}$is 0.75 showing the use of fertilizer and pesticides (Tisdale and Nelson 1975).

The high positive correlations between $\mathrm{SO}_{4}{ }^{2-}$ and $\mathrm{Cl}^{-}$ $(r=0.95), \mathrm{Mg}^{2+}$ and $\mathrm{Cl}^{-}(r=0.95)$, and $\mathrm{Mg}^{2+}$ and
$\mathrm{SO}_{4}{ }^{2-}(r=0.90)$ indicate the impact of agricultural activity. A strong positive correlation is observed between $\mathrm{Mg}^{2+}$ and $\mathrm{Ca}^{2+}$ with indication that most of the ions are involved in various physiochemical reactions, such as oxidation-reduction and ion exchange in the groundwater aquifer system (Udayalaxmi et al. 2010). The $\mathrm{pH}$ was negatively correlated with most of physicochemical parameters.

\section{Ion exchange processes}

It is essential to identify the various changes in chemical composition undergone by groundwater during its travel in the subsurface (Johnson 1979). This can be done using the chloro-alkaline indices, CAI-1 and CAI-2, which are suggested by Schoeller (1977), to indicate ion exchange between the groundwater and its host environment during residence or travel. The value of these indices can be positive or negative. If the value is positive then it explains that the exchange of $\mathrm{Na}^{+}$and $\mathrm{K}^{+}$ions are from water with $\mathrm{Mg}^{2+}$ and $\mathrm{Ca}^{2+}$ ions of the rocks. This indicates a direct base (cation-anion) exchange reaction. In contrast, if the indice is negative then it means that there is an exchange $\mathrm{Mg}^{2+}$ and $\mathrm{Ca}^{2+}$ of the water with $\mathrm{Na}^{+}$ and $\mathrm{K}^{+}$ions from rocks, so the exchange is in indirect base indicating chloro-alkaline disequilibrium. These reactions are known as cation-anion exchange reaction. The chloro-alkaline indices used in the evaluation of the base-exchange are calculated using the following formulas:
Fig. 5 Piper (Trilinear) Diagram for groundwater samples in the study area

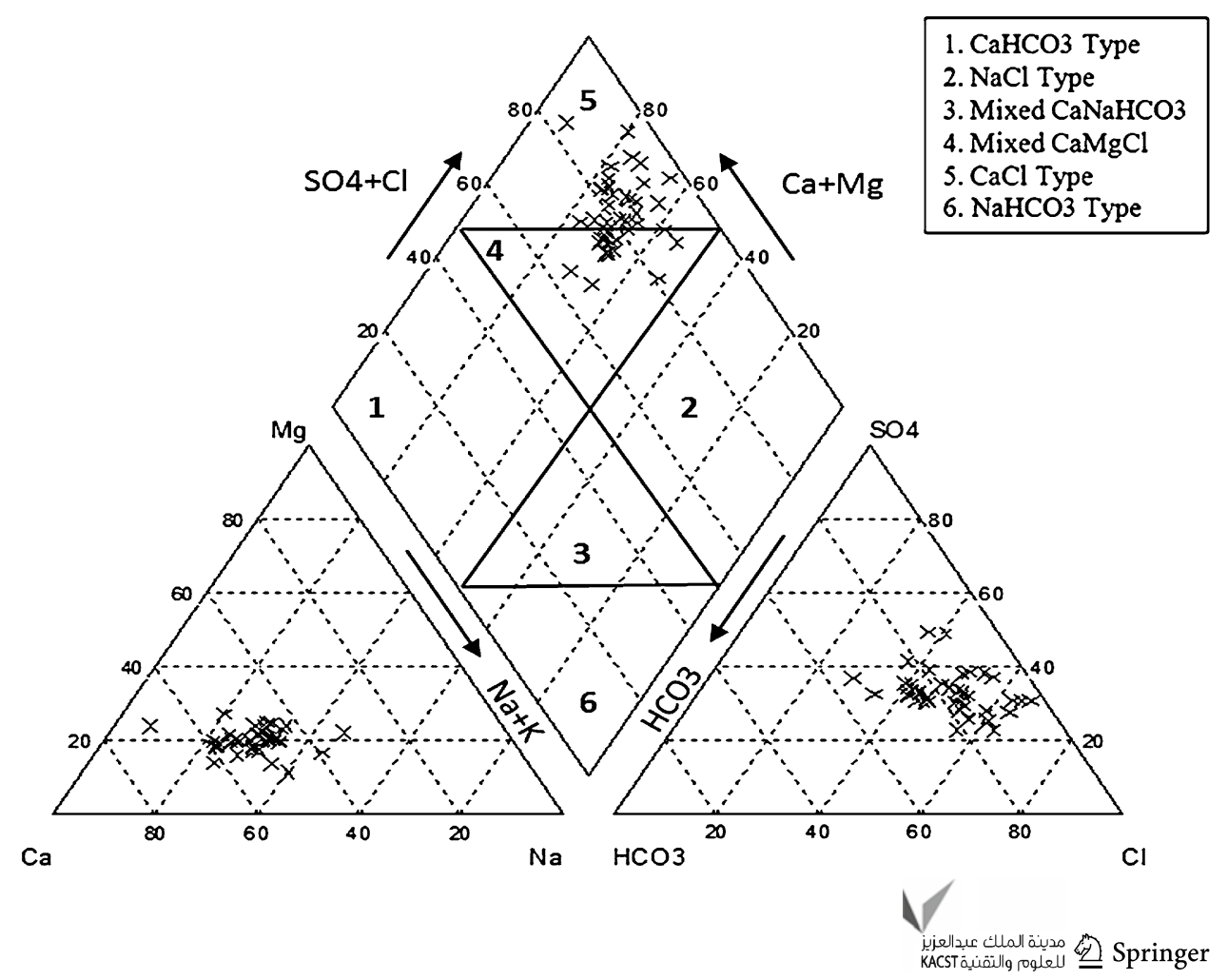


1. Chloro alkaline index $1=[\mathrm{Cl}-(\mathrm{Na}+\mathrm{K})] / \mathrm{Cl}$

2. Chloro alkaline index $2=[\mathrm{Cl}-(\mathrm{Na}+\mathrm{K})]$

$$
/\left(\mathrm{SO}_{4}+\mathrm{HCO}_{3}+\mathrm{CO}_{3}+\mathrm{NO}_{3}\right)
$$

where all concentrations are expressed in epm. The chloroalkaline indices are calculated for the groundwater samples in the study area and it has been found that CAI 1 values range between -0.02 and 0.89 with mean values of 0.35 , while CAI 2 values lie between -0.13 and 0.95 with mean values of 0.40 (Table 1). It is also detected that $88 \%$ of water samples show positive ratios, which is in the form of direct base-exchange reaction. In contrast, $12 \%$ of the samples have negative chloro-alkaline indices, illustrating that they have indirect base-exchange reaction.

\section{Hydro-geochemical facies}

The hydrochemical evolution of groundwater can be understood using the analytical data obtained from groundwater sample as a result of plotting the major cations and anions in the piper Trilinear diagram (Piper 1944). This diagram is considered as one of the most commonly used graphical methods for classifying groundwater based on normalized percentages of major cations and anions. The diagram reveals similarities and differences among water samples because those with similar qualities tend to plot together as groups (Todd 2001). Hydrochemical facies interpretation is a useful tool for determining the flow pattern, origin of chemical histories of groundwater. The piper diagram is useful in bringing out chemical relationships among water in more definite terms (Walton 1970).

The Piper Trilinear diagram for the groundwater samples is presented in the Fig. 5, which clearly explains the variations of cation and anion concentration in the study area. It shows that the majority of groundwater samples during this study fall in the field $\mathrm{CaCl}$ type of water. Some samples fall in mixed $\mathrm{CaMgCl}$ type facies. So, from the plot, alkaline earth $\left(\mathrm{Ca}^{2+}\right.$ and $\left.\mathrm{Mg}^{2+}\right)$ significantly exceeds the alkaline $\left(\mathrm{Na}^{+}\right.$and $\left.\mathrm{K}^{+}\right)$and strong acid $\left(\mathrm{Cl}^{-}\right.$and $\left.\mathrm{SO}_{4}{ }^{2-}\right)$ exceeds the weak acid $\left(\mathrm{HCO}_{3}{ }^{-}\right.$and $\left.\mathrm{CO}_{3}{ }^{2-}\right)$.

Mechanisms of controlling groundwater chemistry (Gibbs ratio)

It is important to study the relationship between the water chemistry and the aquifer lithology. Gibbs (1970) suggests that a diagram that represents the ratio of dominant anions and cations plotted against the value of TDS. These ratios can be divided into two formula, first for cations which is $\mathrm{Na}^{+} /\left(\mathrm{Na}^{+} \mathrm{Ca}\right)$ and the second is for ions, $\mathrm{Cl} /\left(\mathrm{Cl}^{+} \mathrm{HCO}_{3}\right)$ as a function of TDS. This diagram is widely used to evaluate the functional sources of dissolved chemical constituents such as precipitation dominance, rock dominance and evaporation dominance. The chemical analysis of groundwater samples from the study area are plotted in the Gibbs diagram (Fig. 6). This figure shows that the predominant samples fall into the category of rock-water interaction and evaporation dominance fields which suggest that the chemical weathering of rock-forming minerals are influencing the groundwater quality by dissolution of rock through which there is circulation while the data in the evaporation dominance field increase salinity by the increasing ions of $\mathrm{Na}$ and $\mathrm{Cl}$ with relation to increase in TDS and agricultural fertilizers.

Drinking and irrigation water quality

\section{Drinking water quality}

The suitability of groundwater in the study area is evaluated for drinking by comparing with standard guide line values recommended by World Health Organization (1971, 1983). According to WHO specifications, TDS up to $500 \mathrm{mg} / \mathrm{l}$ is the highest desirable and up to $1,500 \mathrm{mg} / \mathrm{l}$ is the maximum permissible level (Table 3). Based on this classification, $72 \%$ of the groundwater samples belong to
Fig. 6 Gibbs diagram for controlling factor of groundwater quality in the study area
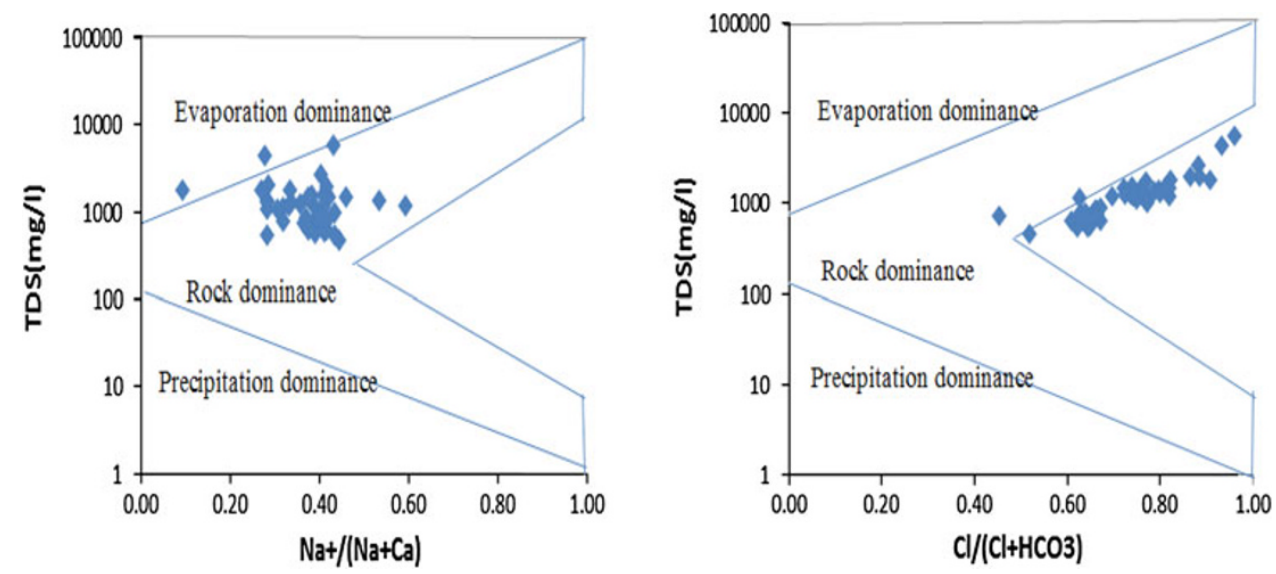
Table 3 Groundwater samples of the study area exceeding the permissible limits prescribed by WHO for drinking purposes

\begin{tabular}{llll}
\hline Parameter & \multicolumn{2}{l}{ WHO international standard $(1971,1983)$} & Wells exceeding permissible limits \\
\cline { 2 - 3 } & $\begin{array}{l}\text { Most desirable } \\
\text { limits }\end{array}$ & $\begin{array}{l}\text { Maximum allowable } \\
\text { limits }\end{array}$ & \\
\hline $\mathrm{pH}$ & $7-8.5$ & 9.2 & Nil \\
$\mathrm{TDS}(\mathrm{mg} / \mathrm{l})$ & 500 & 1,500 & $18,19,23,26-28,31-33,39,41$ \\
$\mathrm{TH}(\mathrm{mg} / \mathrm{l})$ & 100 & 500 & $2,3,5,8,13,14,17-29,31-36,39-41$ \\
$\mathrm{Na}(\mathrm{mg} / \mathrm{l})$ & - & 200 & $18,23,24,27,28,39,40,41$ \\
$\mathrm{Ca}(\mathrm{mg} / \mathrm{l})$ & 75 & 200 & $2,13,17-19,22,23,26-29,31-33,35,39-41$ \\
$\mathrm{Mg}(\mathrm{mg} / \mathrm{l})$ & 50 & 150 & $18,23,27,28,39,41$ \\
$\mathrm{Cl}(\mathrm{mg} / \mathrm{l})$ & 200 & 600 & $2,18,23,24,27,28,31-33,39-41$ \\
$\mathrm{SO}_{4}(\mathrm{mg} / \mathrm{l})$ & 200 & 400 & $2,5,13,17-23,25-28,36,37,39-41$ \\
$\mathrm{NO}_{3}(\mathrm{mg} / \mathrm{l})$ & 45 & - & $\mathrm{Nil}$ \\
$\mathrm{F}(\mathrm{mg} / \mathrm{l})$ & - & 1.5 & \\
\hline
\end{tabular}

Table 4 Classification of groundwater samples based Total Hardness (Sawyer G and McCartly D 1967)

\begin{tabular}{llll}
\hline Range & Water class & $\begin{array}{l}\text { No. of } \\
\text { samples }\end{array}$ & $\begin{array}{l}\text { Percent of } \\
\text { samples }\end{array}$ \\
\hline$>75$ & soft & - & - \\
$75-150$ & Moderately & - & - \\
$150-300$ & Hard & 3 & 7 \\
$<300$ & Very hard & 39 & 93 \\
\hline
\end{tabular}

this value and the remaining exceed the limit. So, this shows that the water can be used for drinking in most of the locations $(1-17,20-22,24,25,29,30,34-38,40,42)$. The classification of groundwater based on the total hardness (Sawyer and McCartly 1967) shows that 3 samples (7 \%) fall in hard category, while the remaining 39 samples $(93 \%)$ are within very hard category (Table 4).

Based on the WHO international standard and Table 3, it is seen that $64 \%$ of groundwater samples in this area exceeds the maximum limit of WHO standard, so this water cannot be used for domestic purposes because it coagulates soap lather, while the rest $(36 \%)$ is good. Concentrations of phosphate $\left(\mathrm{PO}_{4}{ }^{3-}\right)$ and Fluoride $(\mathrm{F})$ are within the permissible limit for drinking.

\section{Irrigation water quality}

The suitability of groundwater for irrigation is depended on the effects of mineral concentrations of water on the soils and plants. The effect of the salts on soils causes change in the soil structure, permeability, and hence, it affects the plant growth. The classification system to evaluate the suitability of water for irrigation use can be determined through the indices such as sodium adsorption ratio (SAR), percent sodium $(\% \mathrm{Na})$, residual sodium carbonate (RSC), permeability index (PI), and USSL classification.
Table 5 Classification of Groundwater samples on the basis of SAR (after Richards 1954)

\begin{tabular}{llll}
\hline SAR & $\begin{array}{l}\text { Water } \\
\text { class }\end{array}$ & $\begin{array}{l}\text { Representative } \\
\text { wells }\end{array}$ & (No. of samples) \\
\hline$>10$ & Excellent & All wells & 42 \\
$10-18$ & Good & Nil & Nil \\
$18-26$ & Doubtful & Nil & Nil \\
$>26$ & Unsuitable & Nil & Nil \\
\hline
\end{tabular}

Table 6 Classification of Groundwater samples on the basis of RSC(after Richards 1954)

\begin{tabular}{lllll}
\hline RSC & Category & Range & $\begin{array}{l}\text { Representative } \\
\text { wells }\end{array}$ & $\begin{array}{l}\text { (No. of } \\
\text { samples) }\end{array}$ \\
\hline$<1.25$ & Good & -72.79 to -2.78 & All & 42 \\
$1.25-2.5$ & Doubtful & - & Nil & Nil \\
$>2.5$ & Unsuitable & - & Nil & Nil \\
\hline
\end{tabular}

Sodium adsorption ratio (SAR) The SAR is the most useful parameter for determining the suitability of groundwater for irrigation purposes because it measures the alkali/sodium hazard to crops (Subrahmani et al. 2005). The sodium enters the aquifer in the study area from rainfall and dissolution from rocks. Due to its effects on soil and plant, $\mathrm{Na}$ is considered one of the major factors governing irrigation water (Richards 1954). It can be determined using the following formula:

$\mathrm{SAR}=\frac{\mathrm{Na}^{2+}}{\sqrt{\left(\mathrm{Ca}^{2+}+\mathrm{Mg}^{2+}\right) / 2}}$

where all the concentration of ions are represented in epm.

The SAR for groundwater in the study is calculated using the above equation and the result of SAR was found 
Table 7 Suitability of groundwater for irrigation based on Percent Sodium

\begin{tabular}{|c|c|c|c|c|}
\hline $\begin{array}{l}\text { Sodium } \\
\text { Percent }\end{array}$ & Water class & Range & $\begin{array}{l}\text { Representing } \\
\text { wells }\end{array}$ & $\begin{array}{l}\text { (Total No. } \\
\text { of wells) }\end{array}$ \\
\hline$<20$ & Excellent & $0-8.05$ & 3 & 1 \\
\hline $20-40$ & Good & $20.53-36.28$ & $\begin{array}{c}1-4,6-23,25-30 \\
32-39,41-42\end{array}$ & 38 \\
\hline $40-60$ & Permissible & $41.60-46.55$ & $40,24,5$ & 3 \\
\hline $60-80$ & Doubtful & - & Nil & Nil \\
\hline$<80$ & Unsuitable & - & Nil & Nil \\
\hline
\end{tabular}

to range between 0.31 and 3.45 with a mean equal to 1.74 . Based on Richards' classification (1954) represented in Table 5, it is observed that all samples can be classified as excellent for irrigation.

Residual sodium carbonate (RSC) The excesses of carbonate and bicarbonate values in groundwater samples over those of calcium and magnesium affect the suitability of groundwater for irrigation. This is expressed as RSC, which is widely used to indicate the suitability of groundwater for irrigation purposes and it can be calculated as follows (Eaton 1950; Ragunath 1987):

$\mathrm{RSC}=\left(\mathrm{CO}_{3}^{-}+\mathrm{HCO}_{3}^{-}\right)-\left(\mathrm{Ca}^{2+}+\mathrm{Mg}^{2+}\right)$

where all ions are expressed in epm. The calculated RSC values of groundwater samples in the study area are found to range from to -72.79 to -2.78 with an average of -12.94 . The classification of groundwater for irrigation purposes according to RSC values indicates that all the groundwater samples are $<1.25$ and hence it is a good category (Table 6).

Negative RSC indicates that sodium buildup is unlikely since sufficient calcium and magnesium are in excess of what can be precipitated as carbonates (Manavalan et al. 2007)
Fig. 7 USSL classification of groundwater samples in the study area

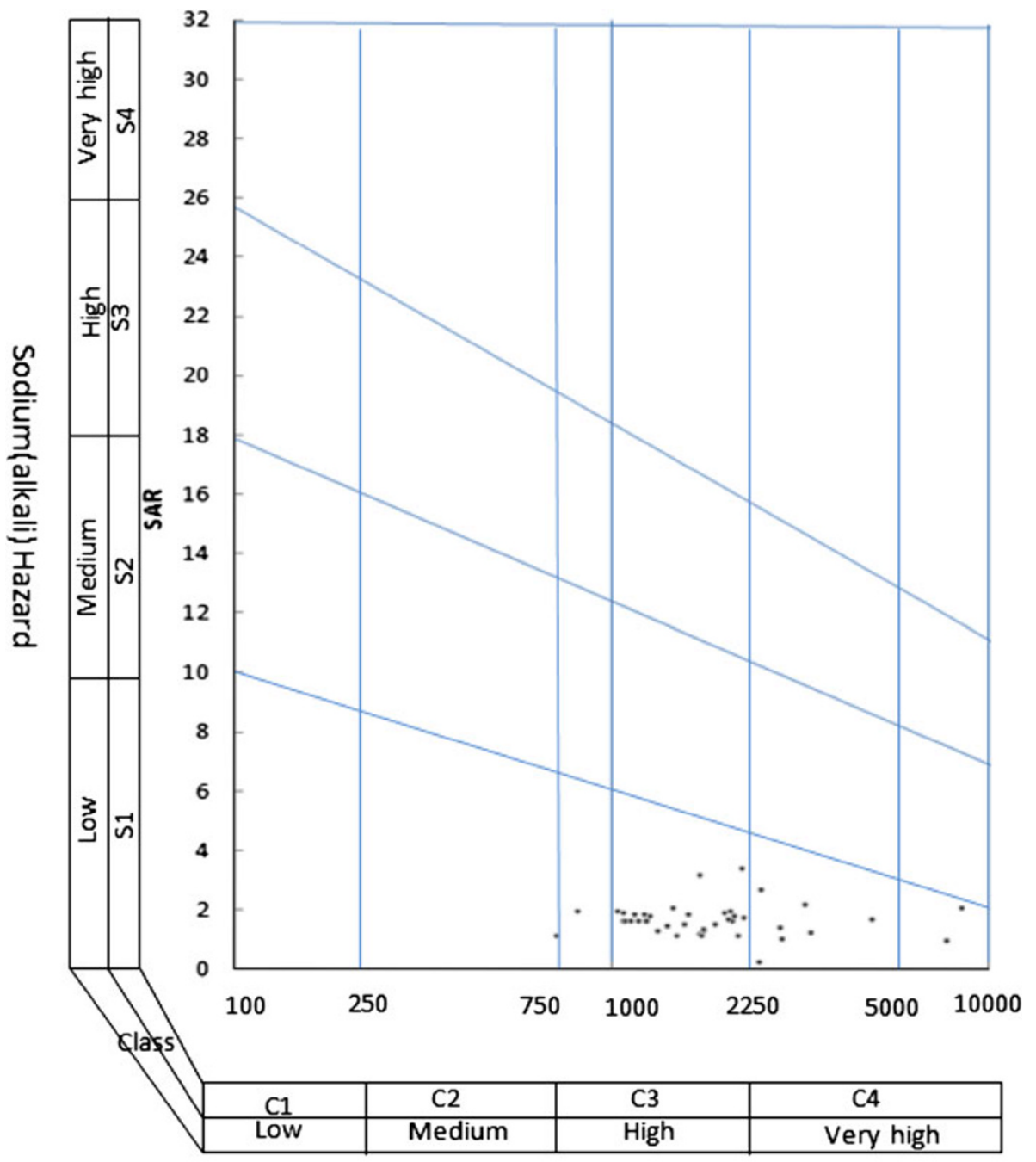

Salinity Hazard 
Permeability index (PI) The permeability index is another parameter which is used to determine the suitability of groundwater for irrigation. This index is proposed by Doneen (1964) to assess probable influence of water quality on physical properties of soils using the following equation.

$\mathrm{PI}=\frac{\mathrm{Na}^{+}+\sqrt{\mathrm{HCO}^{-}} \times 100}{\left(\mathrm{Ca}^{2+}+\mathrm{Mg}^{2+}+\mathrm{Na}^{+}\right)}$

where all ions concentration are express as epm. The permeability index was classified into three classes I, II and III, where classes I and II represent water as good for irrigation with $75 \%$ or more of maximum permeability. The class III water is not suitable with $25 \%$ of maximum permeability. The calculated permeability index for groundwater in the study is found to range from 17.4 to $54.85 \%$ with an average of $40.38 \%$. So it clear that all the groundwater in this area is located in class II, which indicates that water is good for irrigation.

Percent sodium (Na\%) The percent sodium $(\mathrm{Na} \%)$ is another parameter, which can be used to determine the suitability for irrigation that can be calculated using the following expression.

$\mathrm{Na} \%=\frac{\left(\mathrm{Na}^{+}+\mathrm{K}^{+}\right)}{\left(\mathrm{Ca}^{2+}+\mathrm{Mg}^{2+}+\mathrm{Na}^{+}+\mathrm{K}^{+}\right)} \times 100$

where all the concentration are express in epm. The calculated $\mathrm{Na} \%$ in the groundwater samples in the study area range from 8.05 to $46.55 \%$ with an average of $30.40 \%$, which show that the water falls under excellent to permissible limits for irrigation (Table 7). If concentration of sodium is high, it will be absorbed by clay particles, displacing $\mathrm{Mg}^{2+}$ and $\mathrm{Ca}^{2+}$ ions. This exchange process of $\mathrm{Na}^{+}$in water for $\mathrm{Ca}^{2+}$ and $\mathrm{Mg}^{2+}$ in soil reduces the permeability and eventually results in soil with poor internal drainage. Hence, air and water circulations are restricted during wet conditions and such soils are usually hard when dry (Collins and Jenkins 1996; Salah et al. 1999).

Also the classification of water for irrigation can be determined graphically by plotting SAR and EC values on US Salinity Laboratory diagram and the results are shown in Fig. 7, where it shows that most of groundwater samples (78.60\%) fall in the field C3S1, which indicate high salinity and low sodium type which can be used for irrigation on almost all types of soils with little danger of exchangeable sodium (Hem 1989). Also these are some samples $(21.40 \%)$ that fall into the field of C4S1 indicating very high salinity and low alkalinity hazard. This water can be used for plants of good salt tolerance and also restricts the suitability for drainage (Karanth 1989; Mohan et al. 2000).

\section{Conclusions}

The interpretation of the hydrochemical analysis results of 42 water samples from hand dug wells in wadi Sayyah area reveals that the groundwater in this area ranges from fresh to brackish and alkaline in nature. The groundwater is classified as hard to very hard category based on total hardness. The sequence of the abundance of major ions is found in the order of $\mathrm{Ca}^{2+}>\mathrm{Na}^{+}>\mathrm{Mg}^{2+}>\mathrm{K}^{+}$and $\mathrm{Cl}^{-}>\mathrm{SO}_{4}{ }^{2-}>\mathrm{HCO}_{3}{ }^{-}>\mathrm{NO}_{3}{ }^{-}$. The dominated hydrochemical facies of groundwater are $\mathrm{CaCl}$, and mixed $\mathrm{CaMgCl}$. A Gibb's diagram indicates that rock weathering and evaporation are the dominant process controlling groundwater quality in the area. Chloro-alkaline indices 1 , 2 calculations showing that $88 \%$ of the groundwater samples have positive indication exchange of $\mathrm{Na}$ and $\mathrm{K}$ from water with $\mathrm{Mg}^{2+}$ and $\mathrm{Ca}^{2+}$ from the rock, while $12 \%$ of the groundwater samples have negative indication, which indicate just the reverse situation. The assessment of groundwater samples according to World Health Organization for drinking water purposes indicates that the groundwater in the study area is of fresh type in most of the locations (1-17, 20-22, 24, 25, 29, 30, 34-38, 40,42 ) and hence can be used while the rest is brackish which limits its suitability for drinking. The suitability of groundwater for irrigation purpose was assessed from SAR, RSC, Na \%, PI, and USSL plot which varies from good to excellent, which is suitable for irrigation purposes.

It is recommended that irrigation method must be applied in this area to prevent aquifer depletion which results due to over pumping. On the other hand, monitoring the groundwater quality including the possibility of leaching soils of the agricultural land which causes an increase in salinity of the water in this area.

Acknowledgments The author thanks the three anonymous reviewers for their valuable and constructive comments that provided substantial revision of the manuscript; all reviewers are acknowledged for their contribution.

Open Access This article is distributed under the terms of the Creative Commons Attribution License which permits any use, distribution, and reproduction in any medium, provided the original author(s) and the source are credited.

\section{References}

American Public Health Association (APHA) (2005) Standard methods for the examination of water and wastewater, 20th edn. APHA-AWWA-WET, Washington

Bardsen A, Bjorvatn K, Selvig KA (1996) Variability in fluoride content of subsurface water reservoirs. Acta Odontol Scand 54:343-347 
Choi BY, Yun ST, Yu SY, Lee PK, Park SS, Chae GT, Mayer B (2005) Hydrochemistry of urban groundwater in Seoul, South Korea: effect of land-use and pollutant recharge. Environ Geol 48:979-990. doi:10.1007/s00254-004-1205-y

Cobbina SJ, Nyame FK, Obiri S (2012) Groundwater in the Sahelian region of Northern Ghana, West Africa. Res J Environ Earth Sci 4(4):482-2491

Collins R, Jenkins A (1996) The impact of agricultural land use on stream chemistry in the middle hills of the Himalayas, Nepal. J Hydrol 185:71-86

Domenico PA, Schwartz FW (1998) Physical and chemical hydrogeology. Wiley, New York

Doneen LD (1964) Notes on water quality in agriculture. Published as a water science and engineering paper 4001, Dept. of Water Science and Engineering, University of California

Eaton EM (1950) Significance of carbonate in irrigation water. Soil Sci 69:12-133

Freeze RA, Cherry JA (1979) Groundwater. Prentice-Hall, Inc., New Jersy p 553

Gibbs RJ (1970) Mechanisms controlling world's water chemistry. Science 170:1088-1090

Hem JD (1989) Study and interpretation of the chemical characteristics of natural water, 3rd edn. United States Geological Survey Water Supply Paper 2254

Igboekwe MU, Akankpo AO, Udoinyang IE (2011) Hydrochemical evaluation of groundwater quality in Michael Okpara University of Agriculture, Umudike and its environs, Southeastern Nigeria. J Water Resour Prot 3:925-929

Johnson CC (1979) Land application of water-an accident waiting to happen. Groundwater 17(1):69-72

Karanth KR (1989) Hydrogeology. McGraw-Hill, New Delhi

Kurumbein WC, Graybill FA (1965) An introduction to statistical models in geology. McGraw-Hill, New York

Loizidou M, Kapetanios EG (1993) Effect of leachate from landfills on underground water quality. Sci Total Environ 128:69-81. doi: 10.1016/0048-9697(93)90180-E

Manavalan S, Vysetti B, Al Hussin M, Al Jemaili M, Thota, Gnaneshwar R, Ramavati M, Bonathu D, Soday R (2007) Assessment of groundwater quality in a structurally deformed granitic terrain in Hyderabad, India. Environ Monit. Assess 131:117-127. doi:10.1007/s10661-006-9461-9

Mohan R, Singh AK, Tripathi JK, Chowdhary GC (2000) Hydrochemistry and quality assessment of ground water in Naini Industrial area, Allahabad District, Uttar Pradesh. J Geol Soc Ind 55:77-89

Moore TA, Al-Rehalie MH (1989) Geologic map of the Makkah Quadrangle, Sheet 21D. Kingdom of Saudi Arabia, Ministry of Petroleum and Mineral Resources, Directorate General of Mineral Resources. Jeddah, Saudi Arabia

Piper AM (1944) A graphical procedure in the geochemical interpretation of water. Trans Am Geophys Union 25:914-928

Ragunath HM (1987) Groundwater. Wiley Eastern, New Delhi

Rajmohan N, Elango L (2005) Nutrient chemistry of groundwater in an intensively irrigated region of southern India. J Environ Geol $47: 820-830$
Ram Gopal, Gosh PK (1985) Fluoride in drinking water-its effects and removal. Def Sci J 35(1):71-88

Ramesh K, Bhuvana Jagadeewari P (2012) Hydrochemical characteristics of groundwater for domestic and irrigation purposes in Periyakulam Taluk of Theni District, Tamil Nadu. I. Res J Environ Sci 1:19-27

Ramsay CF (1986) Geologic map of the Rabigh Quadrangle, sheet 22D, Deputy Ministry for Mineral Resources, Ministry of Petroleum and Mineral Resources, Jeddah, Saudi Arabia

Richards LA (US Salinity Laboratory) (1954) Diagnosis and improvement of saline and alkaline soils. US Department of Agriculture hand book. p 60

Salah A, Al-Ruwaih F, Shehata M (1999) Hydrogeochemical processes operating within the main aquifers of Kuwait. J Arid Environ 42:195-209

Sawyer GN, McCartly DL (1967) Chemistry of sanitary engineers 2nd edn. McGraw Hill, New York, p 518

Schoeller H (1977) Geochemistry of groundwater. In Groundwater studies-An international guide for research and practice. UNESCO, Paris, Ch. 15, pp 1-18)

Şen Z (1983) Hydrology of Saudi Arabia, Symposium on Water Resources in Saudi Arabia, Riyadh, pp A68-A94

Emmannoel V. Silva-Filho, Renato G. Sobral Barcellos, Christophe Emblanch, Bernard Blavoux, Silvia Maria Sella, Michel Daniel, Roland Simler, Julio Cesar Wasserman (2009). Groundwater chemical characterization of a Rio De Janeiro aquifer, SE-Brazil. J S Am Earth Sci, 27:100-108

Subrahmani T, Elango L, Damodarswamy SR (2005) Groundwater quality and its suitability for drinking and agricultural use in Chithar river basin, Tamil Nadu, India. Environ Geol 47:10991110. doi:10.1007/s00254-005-1243-0

Subrahmanyam K, Yadaiah P (2000) Assessment of the impact of industrial effluents on water quality in Patancheru and environs, Medak district, Andhra Pradesh, India. Hydrogeol J 9(3):297312. doi: $10.1007 / \mathrm{s} 100400000120$

Swan ARH, Sandilands M (1995) Introduction to geological data analysis. Blackwell Science, UK, p 446

Tisdale S, Nelson W (1975) Soil fertility and fertilizer, Macmillan Publishing Co. Inc., New York, p 240

Todd DK (2001) Groundwater hydrology. Wiley, Canada, pp 280-281

Udayalaxmi G, Himabindu D, Ramadass G (2010) Geochemical evaluation of groundwater quality in selected areas of Hyderabad, AP, India. Ind J Sci Technol. vol 3, no 5

United Nations Environmental program (UNEP) (1999) Global Environmental outlook 2000, Earthscan, UK

Walton WC (1970) Groundwater resources evaluation. McGraw Hill Book Co, New York

Wenzel WW, Blum WEH (1992) Fluoride speciation and mobility in fluoride contaminated soil and minerals. J Soil Sci 153:357-364

WHO (1971) International standards for drinking water. World Health Organization, Geneva

WHO (1983) Guidelines to drinking water quality. World Health Organization, Geneva, p 186 